\title{
Quality of Life in rural and urban populations in Lebanon
} using

\author{
SF-36 Health Survey \\ Ibtissam Sabbah ${ }^{1}$, Nabil Drouby ${ }^{2}$, Sanaa Sabbah ${ }^{3}$, Nathalie Retel-Rude ${ }^{1}$ and \\ Mariette Mercier*1
}

Address: ${ }^{1}$ Department of Biostatistics, Faculty of Medicine and Pharmacy, Besançon, France, ${ }^{2}$ Department of Nephrology, University Hospital, Saîda, Lebanon and ${ }^{3}$ Center of Methodology and Technology of the Information, Franche Comté University, Besançon, France

Email: Ibtissam Sabbah - nsdroubi@inco.com.lb; Nabil Drouby - nsdroubi@inco.com.lb; Sanaa Sabbah - nsdroubi@inco.com.lb; Nathalie Retel-Rude - nathalie.retel-rude@univ-fcomte.fr; Mariette Mercier* - mariette.mercier@univ-fcomte.fr

* Corresponding author

Published: 06 August 2003

Health and Quality of Life Outcomes 2003, 1:30

This article is available from: http://www.hqlo.com/content/l/I/30

(c) 2003 Sabbah et al; licensee BioMed Central Ltd. This is an Open Access article: verbatim copying and redistribution of this article are permitted in all media for any purpose, provided this notice is preserved along with the article's original URL.
Received: 24 April 2003

Accepted: 06 August 2003

\begin{abstract}
Background: Measuring health status in a population is important for the evaluation of interventions and the prediction of health and social care needs. Quality of life (QoL) studies are an essential complement to medical evaluation but most of the tools available in this area are in English. In order to evaluated QoL in rural and urban areas in Lebanon, the short form 36 health survey (SF-36) was adapted into Arabic.
\end{abstract}

Methods: SF-36 was administered in a cross-sectional study, to collect sociodemographic and environmental variables as well as self reported morbidity. We analysed a representative sample containing 1632 subjects, from whom we randomly picked 524 subjects aged 14 years and over. The translation, cultural adaptation and validation of the SF-36 followed the International Quality of Life Assessment methodology. Multivariate analysis (generalized linear model) was performed to test the effect of habitat (rural on urban areas) on all domains of the SF-36.

Results: The rate of missing data is very low $(0.23 \%$ of items). Item level validation supported the assumptions underlying Likert scoring. SF-36 scale scores showed wide variability and acceptable internal consistency (Cronbach's alpha $>0.70$ ), factor analysis yielded patterns of factor correlation comparable to that found in the U.S.A and France. Patients resident in rural areas had higher vitality scores than those in urban areas. Older people reported more satisfaction with some domains of life than younger people, except for physical functioning. The QoL of women is poorer than men; certain symptoms and morbidity independently influence the domains of SF-36 in this population.

Conclusion: The results support the validity of the SF-36 Arabic version. Habitat has a minor influence on QoL, women had a poor QoL, and health problems had differential impact on QoL. 


\section{Background}

Measuring health status in a population is important for the evaluation of interventions and the prediction of health and social care needs. The traditional measures of mortality and morbidity, although useful, have nonetheless certain limitations [1]. It goes beyond direct manifestations of illness to study the patient's personal morbidity, that is to say, the various effects that illness and treatments have on daily life and life satisfaction [2]. Indeed, it is now widely acknowledged, in terms of health, that decisions must take into consideration the subject's point of view and his inner feelings towards the experiences he has lived through, i.e. his quality of life (QoL) [3].

Whether or not individuals seek medical attention is less dependent on the "objective" presence of symptoms than on their response to these, or to their general perception that something is wrong with them. Such differences in perception affect utilization of health services to the degree that one individual may seek medical advice while another may not [4] and as health promotion is the process of helping people take control of, and improve their health, changing people's expectations of health is a core element of health promotion [5]. Hence, QoL studies are an essential complement to medical evaluation. QoL is a multi-faceted concept, which encompasses crucial areas such as physical health, psychological well being, social relationships, economic circumstances, personal beliefs and their relationships to salient features of the environment [6-10].

Several scales have been used to measure the different domains of Health Related Quality of Life (HRQL). Certain scales are generic such as the "Sickness Impact Profile" (SIP) [11-13], the "MOS 36 item Short Form Health Survey" (SF-36) [11][14-16], and the "Nottingham Health Profile" (NHP) [11,12], while others are specific to a disease $[4,10][17-24]$, a particular function (e.g pain) or to a group of patients $[25,26]$. The generic scales present the advantage of allowing us to compare the QoL of different populations and/or patients with a variety of diseases, while the specific scales are more sensitive to particular problems of a given population [27-29]. QoL tools must always be validated when used in a new environment [30], because the perception of QoL differs according to the individual situations $[3,28,29,31]$. As most of the tools available in this area are in English, Arab countries are lagging considerably behind in this domain, not only in the development of tools, but also in terms of translation of existing material [12][17][32]. The SF-36 is the most widely used generic QoL instrument world wide because of its comprehensiveness, its brevity and its high standard of reliability and validity [14-16].
Lebanon is a small country (surface area $10,456 \mathrm{~km}^{2}$ ), in active transition characterized by changes in the mortality rate, an increase in life expectancy and the development of chronic diseases related to changes in environment and behavior [33]. Urbanization is one of the major consequences of the demographic transition (85\% in 1996 vs. $60 \%$ in 1970) [34], which can be accompanied by a change in lifestyle and by the emergence of certain diseases [35]. Self reported indicators of health are increasingly used as valid indicators of morbidity and mortality within the general population, and as a complement to investigations based on medical examinations [36,37]. Poor subjective perception of health is recognized as a predictor of increased risk of morbidity and mortality $[38,39]$. In Lebanon, only two studies presented as a QoL survey have been performed: the first studied the wellbeing of households according to a subjective perception of their income [40]. The second evaluated the unsatisfied needs of Lebanese population according to the "Living Conditions Index" (LCI) [41].

In view of the lack of QoL instruments in Arabic, this paper presents and discusses the SF-36 adapted into Arabic in terms of applicability and subject acceptance, psychometric performance and validity; as well as the crosssectional relationship with a selected lists of socioeconomic variables, and environmental variables, in particular the type of habitat (urban vs. rural area) and health variables.

\section{Methods \\ Study design}

From February 2000 to September 2000, we performed a cross-sectional, community-based survey of a random sample of the Lebanese population resident in the territory of South Lebanon (except occupied territory and Palestinian camps), with approximately 383000 residents participating, of whom $1 / 3$ lived in urban areas.

The population base for the survey comes from the 1996 census [42] completed by the data of Mawla and al. [43]. The definition of urban and rural areas in Lebanon was defined in decree number 116 of June 12, 1959, and updated in May 2000 [44], making a distinction between cities and villages.

Sampling was performed randomly at five different levels: (1) the county, (2) the city (in urban areas) or the village (in rural areas), (3) the district, (4) the individual house, (5) the individual subject. In total, we selected 122 families in urban (U) and 244 families in rural (R) areas. This sample would allow us to detect a 10 point difference in SF-36 scores between groups with a fixed norm (a general population), assuming two-sided significance of $5 \%$, with $80 \%$ power [15]. This led us to predict that 366 house- 
holds would be necessary for the survey, taking into account the proportion of urban to rural residents. For each family, we allocated a substitute family, in case of refusal to participate.

At the level of the individual subjects, a random sample was taken within the families according to the number (n) of family members aged 14 years or more at the time of the survey: one person was selected if $\mathrm{n}<4$; two if $3<\mathrm{n}<$ 7 and three if $n>6$.

Inclusion criteria were: age $>13$ years at the time of the visit. Subjects resident in inaccessible areas, such as Palestinian camps and occupied territories in South Lebanon were excluded. Individuals unable to read the questionnaire who were also hard of hearing were excluded, as were very ill or hospitalized patients, severely mentally handicapped patients and subjects unable to understand Arabic.

\section{Data collection}

After identifying eligible subjects, the SF-36 was administered by self-administration or face-to-face interviews (for illiterate persons or those with other difficulties). After that, the interviewer conducted a standardized, structured interview using a pre-tested data collection form to collect information on demographics, socio-economic status (e.g. age, gender, education level, marital status, occupation, and Social Security coverage), environmental variables (religious culture and habitat), financial status (a measure of financial status rated from 1 , very poor, to 5 , very good, [6]). Other variables recorded were the occurence of a grave event during the previous year, satisfaction with work, and global quality of life assessment, which is a measure of the overall QoL status rated from 1 (poor) to 5 (very good). Health problems were measured with a list of common health problems (depression, rheumatic pains, lumbar pains, ...) [45]. A modified version of the Living Conditions Index "LCI-M" (unpublished data) was also assessed to evaluate unsatisfied basic needs in the households.

The SF-36 questionnaire was to be administered before the respondent is asked about other health questions and concurrent illnesses, so that any discussion of health problems does not influence the respondent's answers to the questionnaire.

\section{Cultural Adaptation of the SF-36 into Arabic}

The SF-36 is a generic questionnaire, widely used in various conditions and populations [14-16]. The SF-36 consists of 36 questions that are clustered to yield 8 health status scales: physical functioning (PF), Role-Physical (RP), Bodily Pain (BP), General Health (GH), Vitality (VT), Social Functioning (SF), Role-Emotional (RE), Men- tal Health (MH), Reported Health Transition (HT). Two summary measures aggregate these status scales, namely the Physical and Mental health summary scales. The SF-36 is suitable for self-administration, computerized administration, or administration by a trained interviewer in person or by telephone, to persons age 14 and older. The health concepts described by the SF-36 range in score from 0 to 100, with higher scores indicating higher levels of function and/or better health. The subjects' responses are presented as a profile of scores calculated for each scale.

The translation and cultural adaptation of the SF-36 followed the International Quality of Life Assessment (IQOLA) methodology [46-48]. In the first phase, the SF36 was translated by three bilingual individuals. All three were native Arabic speakers with excellent proficiency in English. Two individuals were graduate students at the American University. The third translator was a physican. Once the three translations were completed, discrepancies between them were resolved by a committee consisting of the translators and three further individuals not involved in the translation process (a sociologist and two epidemiologists). The committee created one unified translation of the SF-36. Because of the difficulties related to Arabic grammar and to the style of Arabic writing, two other Arabic linguistics experts also reviewed the translated version. Then, the Arabic version of the SF-36 was backtranslated by a native english speaker living in Lebanon, who was unaware of the original English language document. Once the backtranslation was completed the committee reconvened to review and resolve the discrepancies between the backtranslation and the original document. Finally, a pretest was conducted with a group (30 subjects) of lay native Arabic speakers. For each item the group was asked to explain how it was understood. Overall, few problems were noted. Discrepancies were resolved by group consensus. The committee overseeing the translation process reviewed the final translation. Globally, the adaptation did not cause any particular problems. In view of cultural differences, certain items were modified in order to fit more closely into the context, consistent with the inherent norms of Lebanese society. Some expressions were modified to suit the context: for example, a mile, several blocks and one block were translated respectively by more than 1000 meters for long distances, a few hundred meters for moderate distances $(200,300,500 \ldots$ meter $)$ and less than 100 meters. On the other hand, both linguists and subjects understood "a good bit of the time" and "most of the time" identically in Arabic. "Bowling or playing golf" was translated to gardening or sport activities simply to represent moderately strenuous physical activities, in view of the differences in leisure traditions between both cultures. Finally, words relating to religious beliefs, such as "only God knows", (inchallah) were formulated for "I don't 
know". Indeed, some of the Lebanese subjects, in particular patients with chronic diseases, found that the questions related to general health were blasphemous, specifically item GH4: "I expect my health to get worse". This was viewed with scepticism, as the subjects maintained that they cannot predict, and that only God knows what lies in store for them. As for the items concerning social relations, some persons expressed the desire that a distinction be made between family relationships, relations with neighbours, and social relationships (i.e. with friends) due to the importance of the family in oriental traditions.

\section{Statistical analysis}

The characteristics of the respondents are described as means and standard deviations for quantitative variables. Qualitative variables are described as percentages and were compared with the chi squared test or Fisher's Exact test where appropriate.

\section{Validation of the SF-36}

We used the IQOLA project approach of item and scale level validation to assess the validity of the SF-36 Arabic version [15,16][46-50]. Individual SF-36 items were recoded, summed and transformed, with missing values imputed as recommended [15]. Subjects with missing scale scores were excluded listwise from the analysis. All tests of significance were two-tailed.

\section{Descriptive statistics}

The mean and standard deviation (SD) for responses to each item and scale were calculated. The percentage of people with scores at the ceiling (percentage of subjects with a score of 100) and floor (lowest level) were calculated for each scale. On the scale level, ceiling and floor effects should be less than $20 \%$ in order to assume that the scale is capturing the full range of potential responses in the population [27].

\section{Acceptability}

The acceptability was tested by studying the percentage of refusals, the percentage of missing items, the percentage of complete questionnaires, the time taken to complete the questionnaire, as well as the acceptability questionnaire, which comprises the percentage of disturbing items, items that were hard to understand or confusing, and the willingness to fill out the questionnaire a second time.

\section{Item level validity}

The item level validity of the SF-36 would be supported if the following Likert scale scoring assumptions were fulfilled: (1) Items belonging to the same scale and measuring the same concept should show approximately the same means and standard deviations. (2) Each item in the scale should have the same correlation with the scale. (3)
For item internal consistency, the correlation between items and the hypothesized scale should exceed 0.40. (4). For item discriminant validity, the correlation between each item and its hypothesized scale (corrected for overlap) should be higher than the correlation between that item and the other scales.

\section{Scale level validity}

Scale level validity would be supported if the SF-36 scores showed substantial variability (measuring the entire spectrum of the hypothesized domain for that scale); if the scales measuring disability (PF, RP, BP, SF, RE) had higher scores than the scales measuring well-being $(\mathrm{GH}, \mathrm{VT}$, $\mathrm{MH})$; and if the reliability of scale scores estimated using internal consistency methods (Cronbach's alpha) was acceptable, namely 0.70 or higher for group comparisons [15][51,52].

\section{Structure validity of the SF-36}

The internal consistency of each scale must be lower than the correlation between that scale and other scales if the SF-36 scales measure a distinct health concept [47]. Furthermore, scales measuring mental health $(\mathrm{MH}, \mathrm{RE}$, and SF) should be more substantially correlated with each other than with other SF-36 scales. Similarly, scales measuring physical health (PF, RP, and BP) should have higher correlation with each other than with other SF-36 scales.

Scale factor analyses were performed using eight scales. Principal component analysis with varimax rotation was carried out on correlation among scales to compare the factorial structure of data with that obtained from the American instrument $[15,16][50]$. The hypothesized physical and mental domains of health underlying the SF36 were identified on factor analysis. The validity of the SF-36 would be further supported if the PF, RP, and BP scales and MH, RE, and SF scales loaded on both domains of health respectively, and if the GH and VT scales loaded on both domains. The authors distinguish three situations: the average score from a scale is substantially correlated if factor loading is greater than 0.7, moderately correlated if factor loading is between 0.3 and 0.7 , and slightly correlated if factor loading is less than 0.3 [15]. "Known groups" validity is a form of construct validity that measures the ability of an instrument to discriminate between groups of subjects who differ with regard to a relevant variable. Both convergent and discriminant validity can be tested [46]. The construct validity of the SF-36 would be supported if groups differing in factors known to affect QoL had SF-36 scores that varied according to $a$ priori hypotheses [15][46].

The validity of known groups was computed by making the association between the sociodemographic parameters, financial status, occurrence of a grave event during 
the past year, satisfaction with work, global quality of life assessment, LCI-M, environmental variables and health problems. The significance of observed differences between groups was assessed using the Mann-Whitney Utest or Kruskal-Wallis 1-way analysis of variance tests of significance for non-normally distributed continuous variables.

\section{Quality of life according to habitat}

This validity of known groups makes it possible to evaluate at the same time the QoL according to habitat, i.e. urban vs. rural. Multivariate analysis was performed to test the effect of habitat on all domains of the SF-36. The adjustments were performed by generalized linear model (Proc GLM of SAS) according to the environment. The confusion variables taken into account were the following: age, gender, means of administration of SF-36, marital status, LCI-M, financial status, occurrence of a grave event during the past year, Global quality of life assessment and type of health problem.

Because of multiple testing, a P-values $<0.01$ was considered to be significant. All data were recorded, and tabulated for analysis using the SPSS 7.5 for Windows statistical package. The GLM analysis was performed using SAS 8.2 (SAS Institute, Cary, NC, U.S.A. 1999-2000).

\section{Results}

The majority of the population welcomed the study. Among the 366 households identified, 347 (94.8\%) accepted to participate in the study, corresponding to 1632 persons. Of these, only 3 refused to participate, and a total of 524 persons completed the questionnaire.

\section{Respondent characteristics}

The characteristics of the respondents according to habitat are given in table 1 . The population ranged in age from 14 to 86 years, with a mean age of 38.8 years $(S D=17.7$, median $=36)$, and there was no difference between urban and rural populations ( 38 vs $39 ; \mathrm{p}=0.47$ ). Women comprised almost two-thirds (61.6\%) of the sample.

$48 \%$ were educated to primary level or lower, and $13.5 \%$ were illiterate, mostly in rural areas. University and higher level education comprised $10.7 \%$. More than half $(54.4 \%)$ of the population studied was not registered with the social security, and there was no significant difference between rural and urban environment in this regard. Regarding the perception of financial status, 26.5\% reported a less than average (very poor and poor) status. Concerning satisfaction in work, 36\% reported partial and total satisfaction. Nearly half $(49 \%)$ of the population reported having experienced a serious event during the last 12 months, including death, divorce, separation, economic crisis and security status of the country. There was no difference here between the urban and rural populations, but there was a significant difference between women and men (respectively $53 \%$ vs. $43 \%$; $\mathrm{p}=0.037$ ); $14 \%$ perceive their QoL (global index) as bad, with a significant disparity between urban and rural environments (respectively $14.5 \%$ vs $13.7 \% ; \mathrm{p}=0.046$ ). Concerning the LCI-M, it shows that $21 \%$ of households have a precarious standard of living. The factors most associated with this underprivileged status were level of education and profession. There was no difference between urban and rural after examination of the global index; although there was a difference in the level of education $(p=0.02)$ and the level of car possession ( $\mathrm{p}=0.02)$.

\section{Validation of the SF-36}

Acceptability of the SF-36 (table 2): No-one refused to answer the questions of the SF-36. In the sample of 524 respondents, the questionnaires were completed in $94.7 \%$ of cases. However, there was a significant difference between the number of self administered questionnaires and those administered by an interviewer $(84.7 \%$ vs. $97.8 \% ; \mathrm{p}<0.0001)$. The amount of missing data was very low, at only $0.23 \%$ of all answered items $(3.4 \%$ of the questions had 1 missing item; $1.1 \%$ had $2-4$ missing items), which indicates that the questionnaire had good acceptability. Nearly two thirds of the incomplete questionnaires had one missing item (18/28). The missing data were spread evenly over the different scales with a minimum of 0 and maximum $1 \% .23 \%$ of the respondents self-administered the questionnaire. The average time of completion of the SF-36 was 8.4 minutes (SD $=2.9$ ), with a minimum of 3 minutes $(0.6 \%$ respondents) and a maximum of 20 minutes $(0.6 \%$ respondents). Only $0.51 \%$ of the items were considered to be confusing. The three most frequently quoted items were: GH2 (I seem to get sick a little easier than other people), RP1 (Cut down the amount of time you spent on work or other activities) and SF2 (how much of the time has your physical health or emotional problems interfered with your social activities?). All respondents accepted to fill out the questionnaire for a second time.

\section{Item level analysis (table 2)}

The item standard deviation tended to be comparable with few exceptions: the range of deviation for responses to questions in a given scale is 0.55 for PF, 0.21 for BP and $\mathrm{GH}, 0.16$ for VT. It is 0.07 or less for the others.

Within each scale, the correlation between items and their hypothesized scale were roughly equal. Success rate $(100 \%)$ was observed in tests of the item internal consistency and tests of item discriminant validity for all scales with the exception of the GH scale: Success rate in the test of item internal consistency was $80 \%$ (the correlation of the GH4 with hypothesized scale was 0.36 ), the success 
Table I: Sociodemographic and environmental characteristics of the subjects.

\begin{tabular}{|c|c|c|c|c|}
\hline Variables & Total n (\%) & Urban n (\%) & Rural n (\%) & P-value \\
\hline $\mathrm{N}(\%)$ & $524(100)$ & $173(33)$ & $351(67)$ & \\
\hline Age (years): & & & & 0.615 \\
\hline $14-19$ & $82(15.6)$ & $30(17.3)$ & $52(14.8)$ & \\
\hline $20-39$ & $208(39.7)$ & $66(38.2)$ & $142(40.5)$ & \\
\hline $40-60$ & $156(29.8)$ & $55(31.8)$ & $101(28.8)$ & \\
\hline 60 and plus & $78(14.9)$ & $22(12.7)$ & $56(16.0)$ & \\
\hline Gender & & & & 0.79 \\
\hline Male & $201(38.4)$ & $65(37.6)$ & $136(38.7)$ & \\
\hline Female & $323(61.6)$ & $108(62.4)$ & $215(61.3)$ & \\
\hline Education (level) & & & & 0.057 \\
\hline Illiterate & $71(13.5)$ & $14(8.1)$ & $57(16.2)$ & \\
\hline Elementary level and lower & $180(34.4)$ & $59(34.1)$ & $121(34.5)$ & \\
\hline Intermediate and secondary & $217(41.4)$ & $78(45.1)$ & $139(39.6)$ & \\
\hline University and higher level & $56(10.7)$ & $22(12.7)$ & $34(9.7)$ & \\
\hline Marital status & & & & 0.57 \\
\hline Single & $185(35)$ & $64(37)$ & $|2|(34.5)$ & \\
\hline Married \& get engaged & $300(57.3)$ & $94(54.3)$ & $206(58.7)$ & \\
\hline Divorced/separated/widowed & $39(7.4)$ & $15(8.7)$ & $24(6.8)$ & \\
\hline Work status & & & & 0.40 \\
\hline Employed & $243(46.4)$ & $79(45.7)$ & $164(46.7)$ & \\
\hline Students & $75(14.3)$ & $28(16.2)$ & $47(13.4)$ & \\
\hline Housewife & $169(32.3)$ & $58(33.3)$ & $111(31.6)$ & \\
\hline Not working ${ }^{\mathrm{a}}$ & $37(7.1)$ & $8(4.6)$ & $29(8.3)$ & \\
\hline \multicolumn{5}{|l|}{ Social security } \\
\hline No & $285(54.4)$ & $88(50.9)$ & $197(56.1)$ & 0.26 \\
\hline \multicolumn{5}{|l|}{ Yes: } \\
\hline National Social Security Fund (NSSF) & $113(21.6)$ & $42(24.3)$ & 7I (20.3) & \\
\hline $\begin{array}{l}\text { Civil Servants Cooperative (CSC) and Army and } \\
\text { Internal Security Forces (ISF) }\end{array}$ & $96(18.4)^{b}$ & $30(17.4)$ & $66(18.8)$ & \\
\hline Private Insurance and others & $30(5.7)$ & $13(7.5)$ & $17(4.8)$ & \\
\hline Religious culture & & & & 0.068 \\
\hline Muslim & $435(83)$ & |5| (87.3) & $284(80.9)$ & \\
\hline Christian & $89(17)$ & $22(12.7)$ & $67(19.1)^{\prime}$ & \\
\hline Financial status & & & & 0.42 \\
\hline Very poor \& poor & $139(26.5)$ & $46(26.6)$ & $93(26.5)$ & \\
\hline Intermediate & $286(54.6)$ & $89(51.4)$ & $197(56.1)$ & \\
\hline Good \& very good & $99(18.9)$ & $38(22.0)$ & $61(17.4)$ & \\
\hline Serious event & & & & 0.47 \\
\hline No & $267(5 \mathrm{I})$ & $92(53.2)$ & $175(49.9)$ & \\
\hline Yes & $257(49)$ & $81(46.8)$ & $176(50.1)$ & \\
\hline Satisfaction with work & & & & 0.39 \\
\hline No & $55(10.5)$ & $22(12.7)$ & $33(9.4)$ & \\
\hline Yes & $188(35.9)$ & $57(32.9)$ & $131(37.3)$ & \\
\hline Not Applicable & $281(53.6)$ & $94(54.3)$ & $187(53.3)$ & \\
\hline Global Quality of life Assessment & & & & 0.046 \\
\hline Very poor, poor & $73(13.9)$ & $25(14.5)$ & $48(13.7)$ & \\
\hline Fair & $205(39.1)$ & $55(31.8)$ & $150(42.7)$ & \\
\hline Good, very good & $246(46.9)$ & $93(53.8)$ & $153(43.6)$ & \\
\hline
\end{tabular}

Abbreviations and Notes: $\mathrm{N}=$ sample size, a: Not working = unemployed, retired, persons of independent means, elderly. NSSF: National Social Security Fund, CSC: Civil Servants Cooperative, ISF: Internal Security Forces, b: CSC = 47 (9\%), army and ISF = 49 (9.4\%); Among all those covered by social security, $7(\mathrm{I} .4 \%)$ people $[3(1.8 \%)$ in urban and $4(1.2 \%)$ in rural areas] had additional health coverage.

rate for item discriminant validity was $95 \%$ (GH1 is more closely or equally correlated with the dimensions PF, BP and VT than its own dimension).
Scale level analysis (table 2)

The floor effect is too low for all scales except (RP and RE). On the other hand, a ceiling effect more than $30 \%$ for 5 scales (PF, RP, BP, SF and RE) and between 3 and 5\% for 
Table 2: Description of scales, tests of item internal consistency and discriminant validity $(\mathbf{N}=\mathbf{5 2 4})$.

\begin{tabular}{|c|c|c|c|c|c|c|c|c|}
\hline \multirow[t]{2}{*}{ Scale } & \multirow[t]{2}{*}{$\mathbf{K}^{\mathbf{a}}$} & \multirow[t]{2}{*}{ Mean (SD) } & \multirow[t]{2}{*}{$\begin{array}{l}\text { Ceiling/ } \\
\text { floor (\%) }\end{array}$} & \multirow[t]{2}{*}{$\begin{array}{l}\text { Item SD } \\
\text { (range) }\end{array}$} & \multicolumn{2}{|c|}{ Range of correlations } & \multirow{2}{*}{$\begin{array}{l}\begin{array}{l}\text { Internal } \\
\text { Consistency } \\
\text { Tests }^{\text {d }}\end{array} \\
\begin{array}{l}\text { Success Rate } \\
\text { (\%) }\end{array} \\
\end{array}$} & \multirow{2}{*}{$\begin{array}{l}\begin{array}{l}\text { Discriminant } \\
\text { Validity Testse }\end{array} \\
\begin{array}{l}\text { Success Rate } \\
(\%)\end{array}\end{array}$} \\
\hline & & & & & $\begin{array}{l}\text { Item - Internal } \\
\text { consistencyb }\end{array}$ & $\begin{array}{l}\text { Item - } \\
\text { Discriminant } \\
\text { validityc }\end{array}$ & & \\
\hline PF & 10 & $81.34(22.81)$ & $30.9 / 0.6$ & $0.3 I-0.86$ & $0.54-0.77$ & $0.11-0.47$ & 100 & 100 \\
\hline RP & 4 & $63.64(40.64)$ & $47.3 / 21.2$ & 0.48 & $0.68-0.74$ & $0.28-0.48$ & 100 & 100 \\
\hline BP & 2 & $68.91(30.68)$ & $38 / 2.9$ & $1.52-1.73$ & 0.80 & $0.34-0.52$ & 100 & 100 \\
\hline $\mathrm{GH}$ & 5 & $66.32(22.93)$ & $3.2 / 1.3$ & $1.22-1.43$ & $0.36-0.66$ & $0.09-0.57$ & 80 & 95 \\
\hline VT & 4 & $60.87(22.54)$ & $5.0 / 1.0$ & $1.44-1.60$ & $0.47-0.56$ & $0.33-0.50$ & 100 & 100 \\
\hline SF & 2 & $68.87(29.66)$ & $30.3 / 3.8$ & $1.34-1.37$ & 0.54 & $0.33-0.51$ & 100 & 100 \\
\hline $\mathrm{RE}$ & 3 & 53.08 (43.39) & $40.3 / 32.3$ & 0.50 & $0.67-0.73$ & $0.31-0.47$ & 100 & 100 \\
\hline $\mathrm{MH}$ & 5 & $62.87(22.53)$ & $5.0 / 0.6$ & $1.51-1.63$ & $0.41-0.59$ & $0.12-0.56$ & 100 & 100 \\
\hline
\end{tabular}

a : Number of items and number of internal consistency tests per scale. b: Correlations between items and hypothesized scale corrected for overlap. c: Correlations between items and other scales. d: Number $=0.40$. e: Number of correlations significantly higer/total number of correlations. SD = standard deviation; \% ceiling (USA): I-56; \% floor (USA): I-24 [20].

Table 3: Reliability and interscale correlations of the SF-36 (Arabic version).

\begin{tabular}{lllllllll}
\hline & $\begin{array}{l}\text { Reliability } \\
\text { Lebanon }\end{array}$ & $\begin{array}{l}\text { Reliability } \\
\text { USA }\end{array}$ & PF & RP & BP & GH & VT & SF \\
\hline PF & 0.90 & 0.93 & & & & & & \\
RP & 0.87 & 0.89 & 0.53 & & & & & \\
BP & 0.89 & 0.90 & 0.48 & 0.55 & & & & \\
GH & 0.72 & 0.81 & 0.52 & 0.42 & 0.44 & & & \\
VT & 0.73 & 0.86 & 0.48 & 0.47 & 0.47 & 0.55 & & \\
SF & 0.70 & 0.68 & 0.39 & 0.40 & 0.47 & 0.41 & 0.56 & 0.43 \\
RE & 0.84 & 0.82 & 0.36 & 0.47 & 0.37 & 0.35 & 0.48 & 0.49 \\
MH & 0.76 & 0.84 & 0.32 & 0.33 & 0.36 & 0.44 & 0.61 & 0.39 \\
\hline
\end{tabular}

$\mathrm{P}<0.001$ for all correlations. ${ }^{a}$ : reliability for the general U. S. population [20].

the others (GH, VT and MH) was observed. Furthermore, mean scores for scales measuring health related disability (PF, RP, BP except RE) were higher than scores for scales measuring well being ( $\mathrm{GH}, \mathrm{VT}$, and $\mathrm{MH}$ except SF). For each scale, the reliability coefficients equaled or exceeded 0.70 , ranging from 0.70 for SF scale to 0.90 for PF scale. The internal consistency of each scale exceeded the correlation between that scale and other scales.

\section{Structure validity of the SF-36}

Factor analysis of the eight SF-36 scales yielded a two-factor solution corresponding to the hypothesized physical and mental domains of health underlying the SF-36. Table 4 shows the Physical Functioning scale (PF, RP and $\mathrm{BP})$ loading most on the "physical" component and least on the "mental component". Also, the MH scale had the highest loading and the VT, SF had stronger loading on the "mental" component than the "physical" component of health. However, RE correlated with both physical and mental components of health rather than with the mental component alone. The GH scale correlated moderately with both components. $63 \%$ of the total variance was accounted for by the first two rotated principal components.

Table 5 gives the correlations between SF-36 and socioeconomic variables. For the totality of SF-36 scales, the scores decrease with age, they are less for women than men, increase with education level, and decrease according to family situation (unmarried subjects have higher scores than married subjects, and married subjects have higher scores than divorcees or widow(er)s). On the other hand, no correlation was observed with affiliation to social security, with the exception of the mental scales i.e. VT, SF, RE and MH. 
Table 4: Correlations between SF-36 scales and rotated principal components in Lebanon.

\begin{tabular}{|c|c|c|c|c|}
\hline \multirow[t]{2}{*}{$(N=524)$} & \multicolumn{2}{|c|}{ Hypothesized Association } & \multicolumn{2}{|c|}{ Rotated Principal Components } \\
\hline & Physical & Mental & Physical & Mental \\
\hline PF & $\mathrm{a}$ & c & 0.79 & 0.21 \\
\hline RP & $\mathrm{a}$ & c & 0.80 & 0.22 \\
\hline BP & a & c & 0.72 & 0.29 \\
\hline $\mathrm{GH}$ & $\mathrm{b}$ & b & 0.55 & 0.47 \\
\hline VT & $b$ & $\mathrm{a}$ & 0.39 & 0.76 \\
\hline SF & $\mathrm{b}$ & a & 0.32 & 0.71 \\
\hline RE & $\mathrm{b}$ & $b$ & 0.41 & 0.52 \\
\hline $\mathrm{MH}$ & c & a & 0.10 & 0.87 \\
\hline \multicolumn{5}{|l|}{ Variancel } \\
\hline Eigenvalues & & & 2.52 & 2.51 \\
\hline
\end{tabular}

Notes: a: strong association $(r>0.70)$; b: moderate association $(0.30<r<0.70)$; c: weak association $(r<0.30)$. ': The percentage of measured variance explained by these two factors is $62.9 \%$.

SF-36 scores were also lower in persons who perceived their financial status as poor; differences were important for all scores of the dimensions. This was the case for satisfaction in work; satisfied subjects perceived better scores than the non-satisfied and inactive subjects. Grave events affected mental dimensions (VT, SF, RE, and $\mathrm{MH}$ ) as well as the GH. The perception of QoL (Global Index) was statistically significantly related to all scores of dimensions of SF-36. Concerning self-reported morbidity; all eight SF-36 scales scores discriminated between groups differing in physical and mental morbidity ( $\mathrm{p}<0.01$ ), but not equally well. The comparisons between patients with a specific health problem and patients without that problem (table 6) showed that patients with asthma, visual and hearing disorders, headache, and varicose veins had in many ways poorer QoL (they had poorer scores on 3 or more dimensions of the SF-36). On the other hand, the QoL of patients with hypertension, depression, insomnia, rheumatic and lumbar pains and osteoporosis, were significantly different for all scales of SF-36. Indeed, patients with diabetes and chronic renal failure have the lowest scores, in particular for the PF and GH scales. Finally, epilepsy patients had lower scores of mental health (VT, SF, $\mathrm{RE}$ and $\mathrm{MH}$ ); patients with back hernia had lower scores of physical health (PF, RP, BP, and GH) and $\mathrm{MH}$.

\section{Quality of life according to habitat}

We observed a difference between urban and rural areas (table 1) in relation to education, religious culture and global QoL assessment; and also for morbidity - varicose veins $(p=0.001)$, depression and anxiety $(p=0.024)$, nephrolithiasis $(\mathrm{p}=0.052)$, visual disorder $(\mathrm{p}=0.015)$ and nocturia $(\mathrm{p}=0.051)$.

In univariate analysis, with the exception of the VT scale ( $p=0.15)$, the place of residence (urban vs rural) has no influence on SF-36 scales. We also find these results in multivariate analysis (table 7). $\mathrm{n}$ the other hand, as regards sociodemographic parameters, age influences only PF, while gender influences PF, RF, BP, GH and VT. Self-reported morbidity significantly influences QoL; for example, depression influences the mental scales (VT, MH and SF) as well as certain physical scales (PF and BP); while rheumatic and lumbar pains, influence the majority of the scales, particularly the physical scales PF, GH and SF. Asthma, even outside attacks, had a negative impact on the RE. Chronic renal failure had an effect on the PF; GH and SF. Disc diseases had a negative effect on the domains of physical functioning, except for RF. Visual disorders are shown to influence $\mathrm{MH}$. This was also shown among those who had experienced a life-changing event during the previous 12 months. Finally, the perception of QoL has significant correlation with the entire domain of SF-36 except PF, RF.

It should be noted that in univariate analysis, the mode of administration of the questionnaire (self-administration vs. Investigator-administrated) influenced to a small extent PF and RE scales, where the scores of those who answered by self administration are slightly higher than those interviewed by an investigator $(\mathrm{p}<0.05)$. In multivariate analysis, this effect is observed (table 7) for the GH and $\mathrm{MH}(\mathrm{p}<0.01)$ and to a lesser extent for VT and SF ( $\mathrm{p}$ $<0.05)$.

\section{Discussion}

The aim of our study was to adapt the SF-36 questionnaire into Arabic and to evaluate QoL in an urban and rural Lebanese population. With regard to the translation of the questionnaire for our study, some responses related to religious beliefs. Item GH4 of general health was considered to be blasphemous. It should be noted that this 
Table 5: Relation between the SF - 36 scale scores and socio-demographic characteristics of the subjects

\begin{tabular}{|c|c|c|c|c|c|c|c|c|}
\hline$N=524$ & PF (SD) & RF (SD) & BP (SD) & GH (SD) & VT (SD) & SF (SD) & RE (SD) & MH (SD) \\
\hline Mean (SD) & $81.3(22.8)$ & $63.6(40.6)$ & $68.9(30.7)$ & $66.3(22.9)$ & $60.9(22.5)$ & $68.9(29.7)$ & $53.1(43.4)$ & $62.9(22.5)$ \\
\hline \multicolumn{9}{|l|}{ Age } \\
\hline $14-19$ & $93.3(8.1)$ & 71.6 (34.0) & $77.3(24.3)$ & $76.3(16.8)$ & $66.2(19.8)$ & $74.8(26.1)$ & $62.6(39.0)$ & $66.7(20.5)$ \\
\hline 20-39 & $89.0(17.2)$ & $73.0(36.4)$ & 74.4 (27.5) & $69.3(21.7)$ & $63.5(22.2)$ & $69.9(28.7)$ & $55.2(42.4)$ & $64.4(21.9)$ \\
\hline $40-60$ & 77.4 (20.9) & $57.5(42.8)$ & $63.3(31.7)$ & $62.0(23.3)$ & $59.2(21.5)$ & $69.9(28.6)$ & $51.7(44.2)$ & 62.7 (22.9) \\
\hline $60+$ & $56.1(22.8)^{*}$ & $42.6(43.8)^{*}$ & $56.6(36.5)^{*}$ & $56.5(25.5)^{*}$ & $51.7(25.3)^{*}$ & $57.7(35.0)^{* *}$ & $40.2(46.3)^{* * *}$ & $55.0(24.1)^{* *}$ \\
\hline \multicolumn{9}{|l|}{ Gender } \\
\hline Male & $84.3(21.9)$ & 71.1 (36.8) & $76.3(28.3)$ & $70.1(21.8)$ & $65.8(23.0)$ & $74.5(28.2)$ & $58.5(42.4)$ & $68.3(22.0)$ \\
\hline Female & $79.5(23.2)^{* * *}$ & $58.9(42.2)^{*}$ & $64.3(31.2)^{*}$ & $63.9(23.2)^{* *}$ & $57.8(21.7)^{*}$ & $65.4(30.1)^{*}$ & $49.7(43.7)^{* * *}$ & $59.5(22.2)^{*}$ \\
\hline \multicolumn{9}{|l|}{ Education } \\
\hline Illiterate & $56.4(26.4)$ & $28.9(39.8)$ & 46.7 (3।.7) & $52.5(25.3)$ & $45.8(22.6)$ & $56.7(3 \mid .3)$ & $29.6(41.6)$ & $47.9(22.2)$ \\
\hline $\begin{array}{l}\text { Elementary \& } \\
\text { less }\end{array}$ & 79.9 (22.9) & $64.6(4 I .8)$ & $67.6(32.8)$ & $64.6(24.2)$ & $59.4(23.6)$ & $68.1(31.2)$ & $48.5(44.6)$ & $61.7(23.3)$ \\
\hline $\begin{array}{l}\text { Intermediate \& } \\
\text { secondary }\end{array}$ & $88.1(17.3)$ & 7I.I (35.5) & $75.4(25.5)$ & $71.2(20.4)$ & $65.5(20.3)$ & $72.3(27.9)$ & $60.2(40.8)$ & $67.2(20.5)$ \\
\hline $\begin{array}{l}\text { University \& } \\
\text { higher }\end{array}$ & $91.2(12.2)^{*}$ & $75.4(33.2)^{*}$ & $76.2(27.2)^{*}$ & $70.4(16.3)^{*}$ & $66.9(18.5)^{*}$ & $73.2(25.0)^{* * *}$ & $69.9(37.5)^{*}$ & $68.6(19.6)^{*}$ \\
\hline \multicolumn{9}{|l|}{ Marital status } \\
\hline Single & $90.8(15.1)$ & $72.2(34.5)$ & $75.9(25.4)$ & $71.9(20.5)$ & $65.8(20.4)$ & 71.5 (27.2) & $58.2(40.3)$ & $66.0(20.7)$ \\
\hline $\begin{array}{l}\text { Married \& } \\
\text { engaged. }\end{array}$ & $77.6(24.0)$ & $61.2(42.8)$ & $66.6(31.8)$ & $64.4(22.6)$ & $59.5(23.3)$ & $68.7(30.3)$ & $52.1(44.7)$ & $62.7(23.2)$ \\
\hline $\begin{array}{l}\text { Divorced \& } \\
\text { widowed }\end{array}$ & $64.7(26.5)^{*}$ & 41.0 (39.9)* & $53.6(36.6)^{*}$ & $54.3(28.3)^{*}$ & $48.5(20.2)^{*}$ & 57.4 (33.9) & $36.7(43.7)^{* * *}$ & $49.4(20.5)^{*}$ \\
\hline \multicolumn{9}{|l|}{ Financial status } \\
\hline $\begin{array}{l}\text { Very poor and } \\
\text { poor }\end{array}$ & $73.6(27.6)$ & $54.3(44.6)$ & $62.5(34.3)$ & $58.5(26.3)$ & $53.1(24.2)$ & $61.0(32.5)$ & $36.8(42.2)$ & $55.6(22.8)$ \\
\hline Intermediate & $82.9(20.7)$ & 65.1 (39.5) & $69.9(29.6)$ & $67.5(21.7)$ & $62.0(20.6)$ & $70.8(28.2)$ & $56.5(42.6)$ & $64.1(22.1)$ \\
\hline $\begin{array}{l}\text { Good and very } \\
\text { good }\end{array}$ & $87.5(18.0)^{*}$ & $72.5(35.6)^{* * *}$ & $75.1(26.8)^{* * * *}$ & $73.7(17.8)^{*}$ & $68.7(22.3)^{*}$ & $74.2(27.6)^{* * *}$ & $65.9(41.0)^{*}$ & $69.5(20.9)^{*}$ \\
\hline \multicolumn{9}{|l|}{ Social Security } \\
\hline No & $81.7(23.5)$ & $61.6(4 \mid .8)$ & $67.8(3 \mid .3)$ & $65.3(24.0)$ & $58.8(23.3)$ & $66.6(29.8)$ & $47.4(43.6)$ & $60.3(22.9)$ \\
\hline Yes & $80.2(22.0)$ & $66.1(39.1)$ & $70.2(29.9)$ & $67.5(21.5)$ & $63.4(21.4)^{* *}$ & $71.5(29.3)^{* * * *}$ & $59.9(42.2)^{*}$ & $65.9(21.6)^{* *}$ \\
\hline \multicolumn{9}{|c|}{$\begin{array}{l}\text { Satisfaction with } \\
\text { work }\end{array}$} \\
\hline \multicolumn{9}{|l|}{ No } \\
\hline Yes & $85.4(17.3)$ & $67.7(38.4)$ & 73.7 (29.2) & $67.9(21.9)$ & $57.3(23.3)$ & 66.1 (33.7) & $39.7(39.6)$ & $57.6(23.1)$ \\
\hline \multirow[t]{2}{*}{ Not Applicable } & $86.9(18.6)$ & $71.9(36.6)$ & $73.3(28.2)$ & $69.8(20.2)$ & $67.6(20.1)$ & $74.5(27.0)$ & $63.3(42.0)$ & $68.2(21.6)$ \\
\hline & $76.8(25.3)^{*}$ & $57.3(42.6)^{*}$ & $65.0(32.0)^{* * *}$ & $63.3(22.9)^{* * *}$ & $57.1(22.9)^{*}$ & $65.7(30.0)^{* *}$ & $48.9(43.7)^{*}$ & $60.3(22.4)^{*}$ \\
\hline \multicolumn{9}{|l|}{ Serious event } \\
\hline No & $82.6(22.6)$ & $66.7(39.5)$ & $70.2(30.4)$ & $70.1(20.5)$ & $63.9(22.5)$ & $73.5(27.5)$ & $59.8(42.8)$ & $68.3(21.4)$ \\
\hline Yes & $80.0(22.9) * * *$ & $60.5(4 I .6)$ & $67.6(31.0)$ & $62.3(24.6) *$ & $57.8(22.2) * *$ & $64.0(31.1) *$ & $46.1(43.0) *$ & $57.2(22.3) *$ \\
\hline \multicolumn{9}{|l|}{ Global QoL } \\
\hline $\begin{array}{l}\text { Very poor \& } \\
\text { poor }\end{array}$ & $64.2(28.8)$ & $43.1(42.3)$ & $56.4(34.8)$ & $45.6(25.4)$ & $40.9(24.5)$ & $51.0(33.9)$ & $28.3(39.9)$ & $42.6(19.8)$ \\
\hline Fair & $81.7(22.8)$ & $60.6(42.2)$ & $64.8(32.1)$ & $64.1(22.9)$ & $58.4(19.8)$ & $64.9(29.9)$ & $46.9(43.1)$ & $59.8(20.4)$ \\
\hline $\begin{array}{l}\text { Good \& very } \\
\text { good }\end{array}$ & $86.1(18.4)^{*}$ & $72.3(36.1)^{*}$ & $76.0(26.9)^{*}$ & $74.3(17.4)^{*}$ & $68.9(19.8)^{*}$ & $77.4(24.8)^{*}$ & $65.6(40.4)^{*}$ & $71.4(20.5)^{*}$ \\
\hline \multicolumn{9}{|l|}{$\begin{array}{l}\text { Self- } \\
\text { administered } \\
\text { questionnaire }\end{array}$} \\
\hline No & $79.3(24.4)$ & $61.7(42.7)$ & $67.8(32.6)$ & $65.6(24.1)$ & $60.3(23.2)$ & $68.7(30.9)$ & $50.5(45.1)$ & $62.6(22.7)$ \\
\hline Yes & $87.9(14.7)^{* * * *}$ & $69.7(32.5)$ & $72.5(23.1)$ & $68.7(18.5)$ & $62.8(30.2)$ & $69.5(25.4)$ & $61.4(36.1)^{* * * *}$ & $63.6(22.1)$ \\
\hline
\end{tabular}

Notes: *: $\mathrm{p}<0.001$; **: $\mathrm{p}<0.01$; ***: $\mathrm{p}<0.05$.

attribute was observed in the translation process of the NHP (Nottingham Health Profile) for use in Arabic- speaking countries [53]. According to Bucholz et al. [54], when confronted with a serious disease, patients find that 
Table 6: Relation between health problems and the mean (SD) SF - 36 scale scores

\begin{tabular}{|c|c|c|c|c|c|c|c|c|}
\hline$(N=524)$ & PF (SD) & RF (SD) & BP (SD) & GH (SD) & VT (SD) & SF (SD) & RE (SD) & MH (SD) \\
\hline $\begin{array}{l}\text { Asthma } \\
(\mathrm{N}=34)\end{array}$ & $\begin{array}{l}72.35(24.74) \\
* *\end{array}$ & $\begin{array}{l}50.73(41.96) \\
* * *\end{array}$ & $\begin{array}{l}58.91 \text { (31.70) } \\
\text { **** }\end{array}$ & $\begin{array}{l}56.09(24.30) \\
* *\end{array}$ & $\begin{array}{l}49.41(21.45) \\
*\end{array}$ & $\begin{array}{l}56.25 \text { (33.04) } \\
\text { **** }\end{array}$ & $\begin{array}{l}36.27(45.22) \\
* * *\end{array}$ & $\begin{array}{l}52.82(21.77) \\
* *\end{array}$ \\
\hline $\begin{array}{l}\text { Hypertension } \\
(N=104)\end{array}$ & $\begin{array}{l}68.03(26.47) \\
*\end{array}$ & $\begin{array}{l}47.59(44.68) \\
*\end{array}$ & $\begin{array}{l}59.70(32.15) \\
*\end{array}$ & $\begin{array}{l}57.45(24.29) \\
*\end{array}$ & $\begin{array}{l}54.18(22.34) \\
*\end{array}$ & $\begin{array}{l}62.38 \text { (32.09) } \\
\text { **** }\end{array}$ & $\begin{array}{l}40.70(44.78) \\
*\end{array}$ & $\begin{array}{l}56.35(20.17) \\
*\end{array}$ \\
\hline $\begin{array}{l}\text { Diabetes } \\
(N=23)\end{array}$ & $\begin{array}{l}55.65(28.26) \\
*\end{array}$ & 48.91 (42.96) & $57.74(36.30)$ & $\begin{array}{l}55.09 \text { (19.93) } \\
* *\end{array}$ & $\begin{array}{l}49.56(22.56) \\
* * *\end{array}$ & $60.33(32.10)$ & $\begin{array}{l}34.78(43.20) \\
* * *\end{array}$ & $\begin{array}{l}54.09 \text { (13.53) } \\
* * *\end{array}$ \\
\hline $\begin{array}{l}\text { Chronic renal } \\
\text { failure } \\
(\mathrm{N}=\mathrm{II})\end{array}$ & $\begin{array}{l}61.82(23.05) \\
*\end{array}$ & $47.73(46.71)$ & $\begin{array}{l}49.45(23.07) \\
* * *\end{array}$ & $\begin{array}{l}42.64 \text { (25.88) } \\
\text { ** }\end{array}$ & $\begin{array}{l}45.91 \text { (19.85) } \\
\text { **** }\end{array}$ & $50.00(34.91)$ & $63.64(45.84)$ & $60.73(14.73)$ \\
\hline $\begin{array}{l}\text { Headaches } \\
(N=270)\end{array}$ & $79.80(23.64)$ & $\begin{array}{l}59.44 \text { (4I.39) } \\
\text { **** }\end{array}$ & $\begin{array}{l}64.69(30.50) \\
*\end{array}$ & $\begin{array}{l}63.43(22.63) \\
*\end{array}$ & $\begin{array}{l}58.90(21.99) \\
* * *\end{array}$ & $67.27(29.06)$ & $50.12(44.04)$ & $\begin{array}{l}58.98(22.35) \\
*\end{array}$ \\
\hline $\begin{array}{l}\text { Migraine } \\
(N=44)\end{array}$ & $76.02(25.64)$ & $52.84(43.54)$ & $\begin{array}{l}59.66(32.56) \\
\text { *** }\end{array}$ & $\begin{array}{l}57.73(27.40) \\
\text { *** }\end{array}$ & $\begin{array}{l}53.18(18.33) \\
* *\end{array}$ & $\begin{array}{l}58.24(31.66) \\
\text { **** }\end{array}$ & $\begin{array}{l}35.6 \mathrm{I}(42.77) \\
* *\end{array}$ & $58.91(21.52)$ \\
\hline $\begin{array}{l}\text { Epilepsy } \\
(\mathrm{N}=27)\end{array}$ & 70.18 (32.95) & $48.15(48.50)$ & $59.81(35.30)$ & 53.5I (33.39) & $\begin{array}{l}45.00(23.53) \\
*\end{array}$ & $\begin{array}{l}50.46(33.88) \\
\text { ** }\end{array}$ & $\begin{array}{l}30.86(4 I .27) \\
* *\end{array}$ & $\begin{array}{l}45.63(20.91) \\
*\end{array}$ \\
\hline $\begin{array}{l}\text { Depression } \\
(N=140)\end{array}$ & $\begin{array}{l}71.93(25.59) \\
*\end{array}$ & $\begin{array}{l}51.25(43.07) \\
*\end{array}$ & $\begin{array}{l}59.00(32.28) \\
*\end{array}$ & $\begin{array}{l}58.17(25.58) \\
*\end{array}$ & $\begin{array}{l}50.96(22.83) \\
*\end{array}$ & $\begin{array}{l}61.87(31.25) \\
*\end{array}$ & $\begin{array}{l}42.14(43.18) \\
*\end{array}$ & $\begin{array}{l}53.17(21.99) \\
*\end{array}$ \\
\hline $\begin{array}{l}\text { Insomnia } \\
(\mathrm{N}=232)\end{array}$ & $\begin{array}{l}72.69(26.16) \\
*\end{array}$ & $\begin{array}{l}51.62(43.33) \\
*\end{array}$ & $\begin{array}{l}60.46(32.34) \\
*\end{array}$ & $\begin{array}{l}58.49(24.24) \\
*\end{array}$ & $\begin{array}{l}53.43(21.78) \\
*\end{array}$ & $\begin{array}{l}60.67(3 \mid .4 I) \\
*\end{array}$ & $\begin{array}{l}41.09(43.06) \\
*\end{array}$ & $\begin{array}{l}55.43(22.14) \\
*\end{array}$ \\
\hline $\begin{array}{l}\text { Rheumatic } \\
\text { pain } \\
(N=14 I)\end{array}$ & $\begin{array}{l}68.26(25.89) \\
*\end{array}$ & $\begin{array}{l}44.45(42.1 \mathrm{I}) \\
*\end{array}$ & $\begin{array}{l}53.25(31.16) \\
*\end{array}$ & $\begin{array}{l}55.40(24.66) \\
*\end{array}$ & $\begin{array}{l}50.66(23.03) \\
*\end{array}$ & $\begin{array}{l}57.53(32.00) \\
*\end{array}$ & $\begin{array}{l}42.91(42.60) \\
*\end{array}$ & $\begin{array}{l}54.69(23.54) \\
*\end{array}$ \\
\hline $\begin{array}{l}\text { Lumbar pain } \\
(\mathrm{N}=240)\end{array}$ & $\begin{array}{l}73.81(24.14) \\
*\end{array}$ & $\begin{array}{l}50.62(42.16) \\
*\end{array}$ & $\begin{array}{l}55.73(31.43) \\
*\end{array}$ & $\begin{array}{l}57.43(24.77) \\
*\end{array}$ & $\begin{array}{l}54.10(22.34) \\
*\end{array}$ & $\begin{array}{l}60.83(32.10) \\
*\end{array}$ & $\begin{array}{l}42.08(42.82) \\
*\end{array}$ & $\begin{array}{l}58.00(22.03) \\
*\end{array}$ \\
\hline $\begin{array}{l}\text { Discopathy } \\
(\mathrm{N}=33)\end{array}$ & $\begin{array}{l}67.42(23.02) \\
*\end{array}$ & $\begin{array}{l}41.67(42.23) \\
*\end{array}$ & $\begin{array}{l}44.58(3 I .4 I) \\
*\end{array}$ & $\begin{array}{l}51.24(23.79) \\
*\end{array}$ & $54.39(23.58)$ & $62.50(31.4 I)$ & $40.40(44.69)$ & $\begin{array}{l}52.97(26.65) \\
* *\end{array}$ \\
\hline $\begin{array}{l}\text { Osteoporosis } \\
(\mathrm{N}=33)\end{array}$ & $\begin{array}{l}54.85(24.22) \\
*\end{array}$ & $\begin{array}{l}33.33(44.05) \\
*\end{array}$ & $\begin{array}{l}49.12(31.76) \\
*\end{array}$ & $\begin{array}{l}44.18(29.00) \\
*\end{array}$ & $\begin{array}{l}75.30(18.20) \\
*\end{array}$ & $\begin{array}{l}48.11 \text { (34.39) } \\
*\end{array}$ & $50.50(44.19)$ & $\begin{array}{l}52.73(20.79) \\
* *\end{array}$ \\
\hline $\begin{array}{l}\text { Varicose } \\
\text { veins } \\
(\mathrm{N}=108)\end{array}$ & $\begin{array}{l}75.97(24.58) \\
* *\end{array}$ & $\begin{array}{l}54.86(4 I .92) \\
\text { ** }\end{array}$ & $\begin{array}{l}60.97(29.62) \\
*\end{array}$ & $\begin{array}{l}62.17(22.50) \\
\text { ** }\end{array}$ & $\begin{array}{l}55.51 \text { (21.96) } \\
\text { ** }\end{array}$ & $\begin{array}{l}63.66(29.92) \\
\text { *** }\end{array}$ & $\begin{array}{l}45.06(44.26) \\
* * *\end{array}$ & $\begin{array}{l}58.15(23.67) \\
\text { *** }\end{array}$ \\
\hline $\begin{array}{l}\text { Visual } \\
\text { disorders } \\
(\mathrm{N}=186)\end{array}$ & $\begin{array}{l}72.66(25.50) \\
*\end{array}$ & $\begin{array}{l}54.17(42.15) \\
*\end{array}$ & $\begin{array}{l}62.17(33.51) \\
*\end{array}$ & $\begin{array}{l}61.54(24.32) \\
*\end{array}$ & $\begin{array}{l}55.56(23.87) \\
*\end{array}$ & $\begin{array}{l}64.72(31.90) \\
\text { *** }\end{array}$ & $49.28(44.82)$ & $\begin{array}{l}58.47(23.01) \\
*\end{array}$ \\
\hline $\begin{array}{l}\text { Hearing } \\
\text { disorder } \\
(\mathrm{N}=3 \mathrm{I})\end{array}$ & $\begin{array}{l}59.51(30.06) \\
*\end{array}$ & $\begin{array}{l}45.16(43.98) \\
\text { **** }\end{array}$ & $\begin{array}{l}55.52 \text { (35.59) } \\
\text { *** }\end{array}$ & $\begin{array}{l}51.42(23.23) \\
*\end{array}$ & $\begin{array}{l}50.16(16.30) \\
*\end{array}$ & $\begin{array}{l}57.26(31.59) \\
\text { **** }\end{array}$ & $40.86(44.48)$ & $58.58(23.11)$ \\
\hline
\end{tabular}

Notes: *: $\mathrm{p}<0.001$; **: $\mathrm{p}<0.01$; ***: $\mathrm{p}<0.05$; Blanks in table indicate a non significant $\mathrm{p}$-value for the eight scale in that test.

the spiritual or transcendental aspect of life becomes a more important determinant of their QoL. In fact, we found that the items that created problems in cultural adaptation were also found to be confusing by the respondents, which lead us to change the Arabic term "cut down" of items RP1 and RE1 to a more clear and less literary term for the same word and also the term "interfere" of items SF1 and BP2 and the term "to get worse" of the GH4.

Concerning acceptability, it was in general very good, no disturbing questions, few confusing items, very low percentage of missing data for items and scales, and the duration of administration of the questionnaire is short $[14,15]$. This reinforces the expected validity (face valid- ity) and therefore makes it possible to confirm the absence of problems related to translation [47].

Concerning the results of the item and scales tests, our results are comparable to those using the American version [15], and to other adaptations performed on French general population [48] and in the English and Chinese population in Singapore [55]. We observe that only PF and BP scales have values of Cronbach's alpha more than 0.90 (see table 3 ) and this may be used at the subject level [15][47,51].

Factorial analysis of the scales yielded results identical to the original version with the exception of the RE scale. The RE appears to measure both physical and mental health (moderate association). This discordance is probably 
Table 7: Influence of habitat on the SF-36 scale scores: multivariate analysis results.

\begin{tabular}{|c|c|c|c|c|c|c|c|c|}
\hline$N=524$ & PF & $\mathbf{R F}$ & BP & GH & VT & SF & RE & MH \\
\hline Habitat & & & & & $* * *$ & 0.10 & & \\
\hline Age & $*$ & & & 0.08 & & & & \\
\hline Gender & $* * * *$ & **** & $* * *$ & $* * *$ & ** & & & 0.06 \\
\hline Self-administered questionnaire & & & 0.08 & $* *$ & $* * *$ & $* * *$ & & $* *$ \\
\hline Serious event & & & & $* * * *$ & & 0.08 & & $*$ \\
\hline Global Quality of life & & & $* * *$ & $*$ & $*$ & $* *$ & $* *$ & $*$ \\
\hline Asthma & & 0.07 & & 0.07 & 0.08 & 0.08 & $* * *$ & 0.08 \\
\hline Chronic renal failure & $*$ & & 0.068 & $* * *$ & 0.07 & $* *$ & & \\
\hline Epilepsy & $* * *$ & & 0.08 & & & $* * *$ & & \\
\hline Depression/anxiety & $*$ & 0.09 & $* * *$ & & $*$ & $* * *$ & & * \\
\hline Insomnia & 0.09 & & & & 0.10 & 0.06 & 0.09 & \\
\hline Rheumatic pain & $*$ & $* * *$ & $*$ & $* *$ & $* * *$ & & & \\
\hline Lumbar pain & $* * *$ & $* *$ & $*$ & $* * *$ & 0.07 & $* * *$ & $* * *$ & \\
\hline Discopathy & $*$ & & * & * & & & & \\
\hline Visual disorder & & & $* * *$ & & 0.06 & & & $* * * *$ \\
\hline
\end{tabular}

Notes: Education was excluded in this analysis in view of the high correlation with mode of administration of the questionnaire $(r=0.46)$ and LClM. Osteoporosis was also excluded in this analysis in view of the high correlation with chronic renal failure $(r=0.56)$. Professional satisfaction was also excluded in view of the high correlation with LCI.-M*: $\mathrm{P}<0.00$ I; **: $\mathrm{p}<0.01$; ***: $\mathrm{p}<0.05$; blanks in table indicate a non-significant GLM for the eight scale in that test.

explained by the nature of the population and not by a structural defect since the criteria of validity of items and scales are satisfactory [49]. These two dimensions (summary scales) physical and mental explain $63 \%$ of the total variability; and even though it is less than that obtained in the U.S. $(68 \%)$, it is nevertheless acceptable (>60\%) [50]. However, factor analysis results can be influenced by many conditions other than the relationship between underlying concepts, including the skewness of scores and sample size [51].

The presence of a relation between the dimensions of SF36 and the sociodemographic and clinical parameter is an important finding as such instruments could be used in therapeutic evaluations [23]. Results indicate that many dimensions of SF-36 depend on age, gender, education, family situation, perception of financial status, satisfaction with work, perception of the QoL and morbidity.

We analyzed which factors have the greatest effect on the scale scores of the SF-36. Multiple regression analysis confirmed that habitat is an independent factor for determining the scores of VT. Patients resident in rural areas had higher VT scores than those in urban areas. The non-difference observed between the different scales scores of the SF-36 may be explained by the rapid evolution of communication means and services in Lebanon [56], internal and external displacements of Lebanese population and especially the definition of rurality. We also found that older people report more satisfaction with some domains of life than younger people, except for the PF. However, limitations in physical functioning not only adversely affect the
QoL and independence of older persons, but also increase the risk of morbidity and mortality [38]. The QoL of Lebanese women, independent of their age, is poorer than that of men; this has been demonstrated for other indicators such as morbidity (unpublished data). Some elements may explain this difference: sexual taboos, traditional role of the woman as guardian in charge of the health of their children, and even their husbands and the elderly, often to the detriment of the woman's own health $[57,58]$. A more sensitive perception of serious events also adds to this phenomenon. Eronen and al. [26], in a cohort of aging Eastern Finnish women, found that some QoL dimensions may improve during aging in postmenopausal women as they age from their fifties into their sixties.

The scores of QoL are lower than American scores, except for the physical scale (PF) [15], which could be due to outcomes such as falls, institutionalization, and death $[38,39]$. In addition, certain symptoms (e.g. lumbar and rhumatological pains), comorbidity (discopathy and visual disorders) as well as neurotic disorders found in this population independently influence the different scales of SF-36, which is in concordance with the results reported by Ware and al. $[15,16]$. Cohen and al. [59] report that depressed patients and patients experiencing high levels of distress report poor sleep quality and decreased QoL. In fact, in our study, multiple regression (GLM) analysis showed that SF-36 domains scores are not affected by diabetes and hypertension, which could be explained by psychological adaptation to chronic disease [2]. The relation between PF, GH and SF of SF-36 and chronic renal failure has been well demonstrated. $[13,15,20,60-62]$. But this 
could not be elicited in our study in view of the small number of patients. Finally, it may also be possible that patients at home differ from hospitalized patients with the same illness, since hospitalization may affect certain domains of QoL in a patient with chronic disease [23]. Mode of administration of the questionnaire by an investigator negatively influences certain dimensions of SF-36 via the age factor, as the majority of illiterate persons are more elderly [40]. This study has certain limitations: it is limited to South Lebanon, because of a lack of resources and time. Certain villages are excluded in view of the security situation. To continue our validation, because this instrument will be utilizable for clinical trials, it is necessary to include an assessment of its responsiveness to change of the group over time [23,27]. The method of test-retest to appreciate the reproducibility of scores along time $[15,51]$ has not been studied. Finally, the absence of a valid reference instrument in Arabic remains a major obstacle for the establishment of concurrent validity as well as predictive validity. Self-reporting of diseases as a measurement of health status also presents several limitations: patients' reports of conditions do not exactly reflect physicians' diagnosis; diseases that have similar symptoms may be misdiagnosed. Some people may also be unable to remember all their diseases [57]. The validity is not limited to this study; wider use and repetition in various situations will establish its validity.

\section{Conclusions}

In conclusion, it can be said that the main assumptions underlying the SF-36 score Arabic version are preserved when compared with the original American form [15] and that it should therefore be possible to use the instrument to measure Health-Related Quality of Life in Lebanon. The use of such an instrument of QoL would be possible and may change the perspective of health care professionals and health decision makers. However, as regards the impact of the area of residency (urban vs. rural) on QoL, further studies must be carried out in other Lebanese regions using an alternative definition of rurality.

\section{Abbreviations}

IQOLA-international quality of life assessment, QoLquality of life, SF-36-short form 36 health survey, PFphysical functioning, RP-Role-Physical, BP-Bodily Pain, GH-General Health, VT-Vitality, SF-Social Functioning, RE-Role-Emotional, MH-Mental Health, HT-Reported Health Transition, SD-standard deviation. LCI-M-living conditions index.modified

\section{Authors' Contribution}

IS participated in the design of the study, carried out data collection, performed the statistical analysis and drafted the manuscript
ND participated in analysis of data

SS participated in data collection

NRR participated in analysis of data

MM conceived the study and participated in its design, statistical analysis and coordination

All authors read and approved the final manuscript.

\section{Acknowledgements}

We are grateful to the subjects who participated in this survey, to Fiona Caulfield for her help with translation and advice on the manuscript, L.

Tayara for useful comments, F. Badran, R. Fatayergi, G. Madhoun, A. Houri, R. Khatib, M. A. Sabbah for their help with the translation of the SF-36. I would also like to thank M. Puyraveau and M. Baud and the interviewers who helped to carry out this study.

\section{References}

I. Hemingway H, Stafford M, Stansfeld S, Shipley M and Marmot M: Is the SF-36 a valid measure of change in population health? Results from the Whitehall II study. British Medical Journal 1997, 315:7118-7|36.

2. Muldoon MF, Barger SD, Flory JD and Manuck SB: What are quality of life measurements measuring? Debate. British Medical Journal 1998, 316:7|30-7|42.

3. Gérin P, Dazord A, Sali A and Boissel JP: L'évaluation de la dépression a la lumière du concept de la qualité de vie subjective. L'Information Psychiatrique 1992, 5(suppl):47-56.

4. McKenna SP, Doward LC and Davey KM: The Development and Psychometric Properties of the MSQOL: A Migraine-Specific Quality-of-Life Instrument. Clinical Drug Investigation 1998, I5:413-423.

5. Carr AJ, Gibson B and Robinson PJ: Measuring quality of life, Is quality of life determined by expectations or experience? $B M]$ 2001, 322:1240-1243.

6. World Health Organization, Division of Mental Health: Field Trial WHOQOL-1 00. Geneva 1995.

7. Organisation mondiale de la santé, Bureau régional de l'Europe: Les buts de la santé pour tous la politique de santé de l'Europe. Copenhague: Série européenne de la santé pour tous 1993, 4:254.

8. Carr AJ, Thompson PW and Kirwan JR: Quality of Life Measures. British Journal of Rheumatology 1996, 35:275-28I.

9. Testa MA and Simonson DC: Assessment of quality-of-life outcomes. New England Journal of Medicine 1996, 334:835-840.

10. Reviriego J, Millan MD and Millan M: Evaluation of the diabetes quality of life questionnaire in a Spanish population. Pharmacoeconomics 1996, 10:614-622.

II. Kaplan RM: Profile versus utility based measures of outcome for clinical trials. In: Quality of life assessment in clinical trials methods and practice Edited by: Staquet MJ, Hays RD, Fayers PM. Oxford, New York, Tokyo: Oxford University Press; 1 1998:69-90.

12. Anderson RT, Aaronson NK, Bullinger M and McBee WL: A Review of the Progress Towards Developing Health-Related Quality of Life Instruments for International Clinical Studies and Outcomes Research. PharmacoEconomics 1996, 10:336-345.

13. Moreno F, Lopez Gomez JM, Sanz-Guajardo D, Jofre R, Valderrabano $\mathrm{F}$ and on behalf of the Spanish Cooperative Renal Patients Quality of Life Study Group: Quality of life in dialysis patients, A Spanish multicentre Study. Nephrol Dial Transplant 1996, I I(suppl 2):125-129.

14. Ware JE Jr: The SF-36 Health Survey. In: Quality of Life and Pharmacoecoeconomics in Clinical Trials Secondth edition. Edited by: Spilker B. Philadelphia: Lippincott-Raven Publishers; 1996:337-345.

15. Ware JE Jr: SF-36 Health Survey Manuel and Interpretation Guide. Second printing. Boston, Massachusetts: The Health Institute, New England Center 1997. 
16. Ware JE Jr: SF-36 Physical and Mental Health Summary Scales: A User's Manuel, 5th printing. Boston, Health Assessment Lab, New England Center I994.

17. Naughton MJ and Wiklund IK: Dimension-Specific Instruments That May Be Used Across Cultures. In: Quality of Life and Pharmacoecoeconomics in Clinical Trials Secondth edition. Edited by: Spilker B. Philadelphia: Lippincott-Raven Publishers; 1996:633-658.

18. Badia $X$, Garcia-Losa $M$ and Dal-Ré R: Ten-language translation and harmonization of the international prostate symptom score: developing a methodology for multinational clinical trials. Eur Urol 1997, 3 I: 129-140.

19. Schipper $\mathrm{H}$, Clinch J, Mc Murray A and Lewitt M: Measuring the quality of life of cancer patients. The Functional living indexcancer: Development and validation. J Clin Oncol 1984, 2(5):472-483.

20. Mingardi G and for the DIA-QOL Group: From the development to the clinical application of a questionnaire on the quality of life in dialysis. The experience of the Italian Collaborative DIA-QOL (Dialysis-Quality of Life) Group. Nephrol Dial Transplant 1998, I 3(suppl I):70-75.

21. Cella DF, Dineen K, Arnason B, Reder A, Webster KA, Karabatsos G, Chang C, Lloyd S, Mo Ma F, Stewart J and Stefoski D: Validation of the functional assessment of multiple sclerosis quality of life instrument. Neurology 1996, 47(I): I30-138.

22. Wasserfallen J-B, Karen G, Schulman KA and Baraniuk JN: Clinical aspects of allergic disease, Development and validation of a rhinoconjunctivitis and asthma symptom score for use as an outcome measure in clinical trials. Journal of allergy and clinical immunology 1997, 100(I):16-22.

23. Schraub S, Mercier M, Eschwège F, Lefebvre JL, Vrousos $C$ and Barthod L: A new quality of life questionnaire for head and neck cancers. Epidemiology and public health 1996, 44(4):346-357.

24. Tsolaki M, Fountoulakis K, Nakopoulou E, Kazis A and Mohs RC: Alzheimer's disease assessment scale: the validation of the scale in Greece in elderly demented patients and normal subjects. Dement geriatr cogn disord 1997, 8:273-280

25. McKinley Rk, Manku-Scott T, Hastings AM, French DP and Baker R. Reliability and validity of a new measure of patient satisfaction with out of hours primary medical care in the united kingdom: development of a patient questionnaire. British medical journal 1997, 3 I 4:7075.

26. Eronen MK, Rankinen T, Rauramaa R, Sulkava R and Nissinen A: Clinical investigation, Does Aging Mean A Better Life for Women? Journal of the American Geriatrics Society 1997, 45(5):594-597.

27. Bollinger M, Power MJ, Aaronson NK, Cella DF and Anderson RT: Creating and Evaluating Cross-Cultual Instruments. In: Quality of Life and Pharmacoecoeconomics in Clinical Trials Secondth edition. Edited by: Spilker B. Philadelphia, Lippincott-Raven Publishers; 1996:659-668.

28. Juniper E: Measuring health-related quality of life in rhinitis. J Allergy Clin Immunol 1997, 99(2):S742-S748.

29. Guyatt GH, Jaeschke R, Feeny DH and Patrick DL: Measurements in Clinical Trials: Choosing the Right Approach. In: Quality of Life and Pharmacoecoeconomics in Clinical Trials Secondth edition. Edited by: Spilker B. Philadelphia: Lippincott-Raven Publishers; 1996:41-48.

30. Anderson RT, McFarlane M, Naughton MJ and Shumaker SA: Conceptual Issues and Considerations in Cross-Cultural Validation of Generic Health-Related Quality of Life Instruments. In: Quality of Life and Pharmacoecoeconomics in Clinical Trials Secondth edition. Edited by: Spilker B. Philadelphia: Lippincott-Raven Publishers; 1996:605-612.

31. Meers C, Hopman W, Singer MA, Mackenzie TA, Morton AR and McMurray M: A comparison of patient, Nurse, and Physician assessment of Health-Related Quality of Life in End-Stage Renal Disease. E-NEPH Archive. Dialysis and Transplantation I995, 24(3): 120-125.

32. Anderson RT, Aaronson NK, Leplège AP and Wilkin D: International Use and Application of Generic Health-Related Quality of Life Instruments. In: Quality of Life and Pharmacoecoeconomics in Clinical Trials Secondth edition. Edited by: Spilker B. Philadelphia: Lippincott-Raven Publishers; 1996:613-632.

33. Ammar W, Jokhadar A and Awar M: Health Sector Reform in Lebanon. Lebanese Medical Journal 1998, 46(6):328-334.
34. World Health Organization: Analysis of National Reports on the Third Evaluation of the Strategy for HFA (Health for AlI). country Lebanon 1997:80.

35. O.M.S: Rapport sur la santé dans le monde 1999 : Pour un réel changement. Genève 1999.

36. Pineault $R$ and Daveluy C: La planification de la santé. Concepts, méthodes, stratégies. 6ème impression. Ottawa: éditions Agence d'ARC inc 1991:481.

37. Coppieters $Y$, Piette D, Kohn L, De Smet $P$ and health inequalities: self-reported complaints and their predictors in pupils from Belgium. Epidemiology and public health 2002, 50(2): I 35- I 46.

38. Painter $P$, Stewart $A L$ and Carey S: Physical Functioning: Definitions, Measurement, and Expectations. Advances in Renal Replacement Therapy 1999, 6:1 10-123.

39. Ifudu O, Paul HR, Homel $P$ and Friedman EA: Predictive Value of Functional Status for Mortality in Patients on Maintenance Hemodialysis. Am J Nephrol 1998, I 8:109-1 16.

40. Central Statistics Administration: Conditions de vie des ménages en 1997. Etudes statistiques No 9. Lebanese Republic 1998.

4I. Researchers Group: Kharitat ahwal al maiicha fi loubnan Edited by: Ministry of Social Affairs, UNDP. Beirut: Dar al Farabi; 1998: 173. Published in Arabic

42. Ministry of Social Affairs, UNDP: Housing and Population Database. CD-ROM for Windows 1996.

43. Mawla M, Awada A, Chreim Z and Fahs R: Mohafazat el Nabatieh, Idara, gographia, tourath. Ière édition. Liban: Dar Bilal éditeur 1998:334. Published in Arabic

44. Decree I 16 of I 2 June 1959:. In: Kawanin Loubnan, majmouat al noussouss atachriiyah wa altanzimiya 6th edition. Edited by: Sader. Beirut, Dar al manchourat alhoukoukiya; 1992:6030-6040.

45. World Health Organisation: The International Statistical Classification of Diseases and Related Health Problems, tenth revision, volume I, ICD-I0. Geneva World Health Organisation 1993.

46. Gandek B and Ware JE Jr: Methods for validating and norming translations of health status questionnaires : the IQOLA project approach. J Clin Epidemiol 1998, 5 I:953-959.

47. Ware JE Jr, Gandeck BL, Keller SD and and the IQOLA Project Group: Evaluating Instruments Used Cross-Nationally: Methods from the IQOLA Project. In: Quality of Life and Pharmacoecoeconomics in Clinical Trials Secondth edition. Edited by: Spilker B. Philadelphia: Lippincott-Raven Publishers; 1996:681-692.

48. Leplege A, Ecosse E, Verdier A and Perneger TV: The French SF36 Health Survey: Translation, cultural adaptation and preliminary psychometric evaluation. J Clin Epidemiol 1998, 51:1013-1023.

49. Leplège $A$, Mesbah $M$ and Marquis $P$ : Analyse préliminaire des propriétés psychométriques de la version française d'un questionnaire international de mesure de qualité de vie: le MOS SF-36 (version I.I). Rev Epidém et Santé Publ 1995, 43(4):37I-379.

50. Ware JE Jr, Kosinski M, Gandek B, Aaronson NK, Apolone G, Bech P Brazier J, Bullinger $M$, Kaasa $S$, Leplège $A$, Prieto $L$ and Sullivan $M$ : The factor structure of the SF-36 Health Survey in 10 countries: Results from the IQOLA Project. J Clin Epidemiol 1998, 5 I: I I59-I I65.

5I. Nunnally JC and Bernstein IH: Psychometric Theory. McGraw-Hill 31994:752.

52. Cronbach LJ: Coefficient alpha and the internal structure of tests. Psychometrika I95I, I6(3):297-334.

53. Hunt SM: Cross-cultural issues in the use of quality of life measures in randomized controlled trials. In: Quality of life assessment in clinical trials methods and practice Edited by: Staquet M/, Hays RD, Fayers PM. Oxford, New York, Tokyo Oxford University Press; 1998:50-67.

54. Buchholz W: Assessment of Quality of Life, correspondance. The New England Journal of Medicine 1996, 335:520.

55. Thumboo J, Fong K-Y, machin D, Chan S-P, Leong K-H, Feng P-H, Thio S-T and boey M-L: A community-based study of scaling assumptions and construct validity of the English (UK) and Chinese (HK) SF-36 in Singapore. Quality of Life Research 200I, I0:175-188

56. Malek P, Arzouni K, Adam E, El Ratel A, Faraj P, Aoun D, Rizk HS and Tawil W: El wafi fi jougrafia, 4eme partie, pour la classe de 3ème. Beyrouth 21995. Published in Arabic

57. Aïach P: De la mesure des inégalités: enjeux socio-politiques et théoriques. In: Les inégalités sociales de santé Edited by: Leclerc A, 
Fassin H, Grandjean H, Kaminski M, Lang T. Paris, Editions La Découverte/ INSERM; 2000:83-91.

58. Drulhe M: Santé et société, le façonnement sociétal de la santé. Paris: Sociologie d'aujourd'hui, Presse Universitaires de France I 1996:390.

59. Cohen L, Littlefield C, Kelly P, Maurer J and Abbey S: Clinical investigations, Predictors of Quality of Life and Adjustment After Lung Transplantation. Chest 1998, I I3(3):

60. Evans RW, Manninen DL, Garrison LP Jr, Hart LG, Blagg CR, Gutman RA, Hull AR and Lowrie EG: The quality of life of patients with End-Stage renal disease. The New England Journal of Medicine 1985, 3 I 2(9):553-559.

61. Mingardi G, Cornalba L, Cortinovis E, Ruggiata R, Mosconi $P$ and Apolone G for the DIA-QOL Group: Health-related quality of life in dialysis patients. A report from an Italian study using the SF-36 Health Survey. Nephrol Dial Transplant 1999, 14:1503-1510.

62. Fujisawa M, Ichikawa $Y$, Yoshiya $K$, Isotani S, Higuchi A, Nagano S, Arakawa S, Hamami G, Matsumoto $O$ and Kamidono S: Assessment of health-related quality of life in renal transplant and hemodialysis patients using the SF-36 Health Survey. Urology 2000, 56(2):20I-206.

Publish with Bio Med Central and every scientist can read your work free of charge

"BioMed Central will be the most significant development for disseminating the results of biomedical research in our lifetime. "

Sir Paul Nurse, Cancer Research UK

Your research papers will be:

- available free of charge to the entire biomedical community

- peer reviewed and published immediately upon acceptance

- cited in PubMed and archived on PubMed Central

- yours - you keep the copyright

Submit your manuscript here:

http://www.biomedcentral.com/info/publishing_adv.asp
BioMedcentral 